Ingrid Wotschke*

\title{
Socio-regional speech versus "Oxford accent" - trends and fashions in the pronunciation of English English
}

\begin{abstract}
Post-War years have brought new speech habits and evaluations on grounds of so far unprecedented social contacts between the classes. The following paper will focus on recent articulatory developments together with their socio-economic roots and psychological implications, to assess the effects of cross-cultural influence on educated Southern British English.
\end{abstract}

\section{The social relevance of accent in England}

\subsection{Regional speech surviving}

It is an acknowledged fact that most English people are not speakers of what is commonly called Standard English (cf. Trudgill (1990), 2 f.) ${ }^{1}$ but have various degrees of dialect forms in their speech, depending on their social background, education and profession. Even those who by birth or education or both had the chance to acquire a widely acceptable grammar and usage overwhelmingly have a local accent, i.e. they are displaying a certain amount of regional articulations and intonation patterns in their otherwise "standardized" speech. So regional accent

1 The validity of this socially biased and increasingly controversial term has been seriously questioned by linguists (cf. Bailey (1987), 399 ff.; Trudgill (1975), 27). The same refers to the term "Received Pronunciation" (RP), which has likewise been rejected (cf. Macaulay (1988), 115 ff.) but is still widely used in linguistic discussion.

* Ingrid Wotschke

Otto-von Guericke-Universität, Institut für fremdsprachliche Philologien

$P S F$

D-39016 Magdeburg

Hermes, Journal of Linguistics no. 17 - 1996 
permeats the pronunciation "cone" or "pyramid" (cf. Trudgill (1979), 11; Halliday (1968), 148) from bottom to top, except for the tiny tip of the traditionally educated, who acquired the so-called "Received Pronunciation" $(\boldsymbol{R P})$ together with upper(middle)-class speech in their early lives. For the vast majority of English speakers, however, the number and degree of accented speech forms is but "a question of relatively more or less" along a "dialect continuum" (cf. Trudgill (1975), 22; Giles, Powesland (1975), 21), with regional and social aspects closely interwoven.

As anywhere else in the world, the traditional social seclusion of rural areas has led to a particularly strong survival of dialect forms in popular as well as in educated speech. On grounds of geographical distance from the Capital and of different historical developments and regional characteristics, the North preserves a considerable number of original dialect and older standard forms and consequently shows the greatest deviation from the Southern prestige accent (cf. Trudgill (1979), 12). So Northern vernacular forms like [hiem] or [(w)ய̈m] for home (Köppl et al. (1983), 40), [gründ] for ground and [kن̈ 'l] for coal (Trudgill (1979), 12) or conservative dialect words like yat for gate and loup for jump (ib. 14) are of considerable linguistic significance. Nevertheless, the smaller articulatory differences in the South East as an open diphthong [U $\mathrm{U}$ ] in home or a glottal stop [?] for intervocalic or final / $\mathrm{t} /$ in water and hot are socially highly distinctive, and there are also vernacular characteristics such as word initial [d] for /D/ in that or (late medieval) long [i:] for /âे/ in hide that are more obviously different from what is usually considered educated English (Barnickel (1982), 157). Of course, the number of original dialect speakers has been steadily diminishing since widespread industrialization and the general introduction of schooling made society more mobile towards the end of the last century. About that time the "deterioration" of dialects went on with such speed and intensity that in 1913 H. C. Wyld made an urgent plea for monographs "of the rapidly disappearing Regional Dialects ... and of the ever-increasing number of Modified Standards or Class Dialects ... in respect of well-marked social boundaries" (Spencer (1958), 10). In the following decades, with the further growth of industry and the corresponding decline of the traditional rural communities, original country dialects were almost completely dying out and their place was taken by industrial accents in connection with the 
local urban vernaculars. Half a century after Wyld, in the time of the compilation of evidence for the Survey of English Dialects (1971) and the Linguistic Atlas of England (1978) ${ }^{2}$, pure local speech was already a rare relic only found among the oldest of the rural population.

However, modern times have changed but not exterminated regional speech, and English dialects are now "far from dead" (Wright (1974), 154; cf. Leith (1983), 114; Wakelin (1984), 70), living on to various degrees in the speech of the younger generations. Whereas Traditional Dialects have become a shrinking minority almost completely confined to English, Scottish and Irish rural areas and some North and West English urban communities, new Modern Nonstandard Dialect areas (Trudgill (1990), 5) ${ }^{3}$ have originated together with the large industrial centres of the London-based area, North West England and the North Eastern costal areas. In the course of this development traditional isoglosses were shifting or gaining additional weight like the Northern dialect boundary now parting North England from Scotland, and the Central-Northern boundary separating Northerners from Southerners in England. Whole Traditional Dialect areas in the South and Central East, the Eastern South West and parts of East Anglia have been swallowed up by the London-based Home Countries Modern Dialect area, while Northern dialects are about to disappear under the influence of the Central North with its totally new industrial dialect areas around Birmingham, Liverpool, Stoke and Derby (Trudgill (1990), 76 ff.; cf. Hansen (1986), 213 f.). In result of those changes the majority of broadly accented speakers of the traditionally vernacular-speaking classes, travelling to work in towns or factories or living and working in the industrial centres, display "a confusing mixture of dialect and accent" (Ellis (1972), 877). Locally, dialects are merging in an extremely mobile social world, and South Eastern accent features as close [i] in very, extra dark [ن̈] in milk and glottal stop /?/ for / $t /$ in better have spread fast northwards and westwards over dialect boundaries (cf. Trudgill (1990), 77 f.). Again others are dying out on their traditional

2 On the basis of the Survey's material compiled since 1945 and completed between 1962 and 1971 by Harold Orton, Eugen Dieth and eleven fieldworkers, the Linguistic Atlas of England was edited at the university of Leeds in 1978 (cf. Orton et al. (1978), Introduction).

3 For detailed description of Traditional and Moderne Dialect features cf. Peter Trudgill (1990), 19 ff., 67 ff. 
territories as North West Midland [=g] in long and rhotic speech, which seems "unlikely to survive for more than a century" (ib.). Regarding the survival of historical dialect features, modern industrial speech has preserved a considerable number of old regionalisms, among them nearly unrecognizable vernacular forms as fleffs or flecks for flies or guttural [x] in switch t'leyght on (Wright (1979), 48 ff.). Besides, there are younger standard forms, vulgar language and rhyming slang like Cockney trouble and strife for wife, Dickie Dirt for shirt and many others (Smith (1969), 7; Wright (ib.) 88 f.). Sounds are inserted in cornder, umberella and deleted in thunner, (be)cos, Satdy (Wright (ib.) 47) which, though nothing new, is branded ignorant and vulgar. As linguistic judgements are made on social grounds, urban accents or dialects have from the start been connected with the dirt and the ugliness of industrial life and confined to the bottom of the social scale, in contrast to the remains of the traditional country dialects which for many still retain an aura of the quaint and the charming. This public attitude, together with the general difficulty of examining newly arisen linguistic phenomena, may have led to the fact that very little research was done into the city or industrial dialects until the 1970's when dialect forms and accented speech became increasingly viewed as indicators of social background, education and occupation and consciously related to social class in England.

\subsection{Accent as social marker}

Closely linked to personal surroundings, experiences and convictions, accent is always felt to be an important identity marker by the speaker and perceived as a significant social indicator by the listener, the more so as its immediate psychological effect makes it a kind of "social barometer" (Boomer (1976),50) and thus a decisive factor in social interaction. Although there is a broad variation in listeners' reactions to socio-regional accents in England (cf. Giles, Powesland (1975), 21 ff., $163 \mathrm{ff}.)^{4}$, the most serious social gap has for long been that between an "Oxford accent" (i.e. RP) and all other variants of the language. Characteristically, no other speech style in the whole of Britain was considered appropriate for the purposes of National Broadcasting but

\footnotetext{
4 Special research into social speech evaluation is presented by Howard Giles (1972),
} $168 \mathrm{ff}$. 
Received Pronunciation as defined by Daniel Jones, which proves not only the great social prestige of the accent but also its high degree of sociolinguistic consolidation even before the advent of the radio. After that the $\boldsymbol{B B C}$ must have contributed considerably to the further spreading of upper(-middle)-class speech and, above all, to the strengthening of a public notion of its linguistic "qualities". The radio did for $\boldsymbol{R} \boldsymbol{P}$ what general schooling had done for the spread of language standards half a century before: Being carried to every corner of the country, the "voice of authority" created an image of the "best", the most "correct", and the most "beautiful" form of speech (O'Donnell, Todd (1980), 91). In social relationships, whereas “BBC-English" became linked in the public mind with high social standing and intellectual competence, local speech was increasingly associated with lower social levels, lack of education and lower competence (cf. Giles, Powesland (1975), 66 ff.; Trudgill (1975), 56), and even accented speakers themselves became convinced by the influence of the media and their own social experience that they "couldn't speak English" (Trudgill (1974), 20; cf. Halliday (1968), 165; O'Donnell, Todd (1980), 91) and that their regional speech must really be inferior to a standard voice.

Local speech could, indeed, be a serious obstacle to social ambitions, which was particularly strongly felt by those of lower middle-class background who were aiming at higher education and a more prestigious career. No wonder that in an opinion poll of 1972 it was the middle-class group that considered speech the most obvious social barrier ranging before money, education, job and family, and for subjects of all social backgrounds, speech was "the most important indicator of class" (Gimson (1975), 152). As the awareness of antagonisms sharpened together with growing mobility and the resulting new contacts and relations between the classes, language standards were increasingly felt to be "a badge or a barrier" to identify and separate social groups (Quirk (1968), 68; cf. Trudgill (1974), 34). Of course, most members of the lower strata had always deeply despised "posh" or "lah-di-dah", while keeping to their local language habits and refusing to bend to any standard of upper-class provenance. But in post-War years speech differences became most depressingly felt in connection with jobs and careers that required a certain amount of education and were closed to those of working-class background with broad local accents. There were obvious disadvantages in the urban areas where 
"non-RP" began to be experienced as a kind of social deficiency bearing an immediate "threat to existence" (Kelman (1972), 197). It was the time when in the eyes of many an "accent bar" acted "like a colour bar" (Abercrombie (1965), 15; cf. Halliday (1968), 165) depriving people of their opportunities and what was even worse, of their social dignity.

A number of linguists pointed to the "delicate and explosive" nature of the subject (Spencer 11) and to the large scale of emotions, reaching from deep admiration for the prestige accent to utmost hostility and disgust, not only in Britain but all over the English-speaking world. So the dominating role of standard speech as a whole was seriously questioned by linguists like David Abercrombie, Ch.-J. N. Bailey, Peter Trudgill and others, who stressed the equal validity of all variants of English in the common belief that, as Trudgill put it, "standard English is simply no better and no worse than any other dialect" (Trudgill (1975), 27); cf. Abercrombie (1957), 46 ff.; Bailey (1987), 401). When he, nevertheless, called its socially conspicuous $\boldsymbol{R P}$-articulation "the most prestigious accent" in the late seventies (Hughes, Trudgill (1979), 12) and A. C. Gimson mentioned the "great prestige... still attached to this implicitly accepted social standard of pronunciation" in his 1980 API (Gimson (1980), 89), these judgements characterize the prevailing middle-class attitude which, to various degrees, has always been influenced by the upper social strata in England. For in spite of massive aversion to the Southern-based prestige accent, many of middle-class background even now uphold its image as a highly desirable social value worth being aspired and preserved. And, although the "Oxford accent" has lost its dominant position in many fields, it has retained much of its attractiveness for the upwardly mobile lower middle class.

\subsection{Code-switching, convergence and change}

Under post-War social conditions, with growing contacts and opportunities for many, the wide confrontation of increasing numbers of accented speakers with prestigious speech provoked unprecedented consideration of the quality of speech forms, implying personal decisions and consequences. Growing educational opportunities and prospects also for the lower strata, particularly for the lower middle class, made the adoption of prestigious speech forms more desirable and the linguistic results of upward convergence and code-switching (cf. 
Bourke (1979), 57 f.; Giles, Powesland (1975), 171 ff.) more obvious than before. While many of middle-class and upper working-class background now consider mild local speech normal in personal intercourse with relatives or friends, a move in the direction of more prestigious articulations is generally held to be essential in education and occupation, unless unskilled, and often found among strangers and in public life. Meanwhile normal style-shifting in lower-, middle- and upper working-class speech has taken the form of an enforced bilingualism with its paralysing effects on social interaction, personal opportunities and a free development of the speaker's personality - a fact that led to urgent calls for more respect by teachers for the regional speech of their pupils in order to prevent intellectual backwardness and the resulting social disadvantages in later life (cf. Trudgill (1975), 57). However, beside temporary accent convergence and code-switching some lasting change towards prestigious speech seems to be going on in the younger dialect-speaking generations, like the gradual loss of the traditional distinction between [u:] in nose and [U $\mathrm{U}]$ in knows in favour of / $\mathrm{U} /$, the replacement of $[\mathrm{A}]$ by / $\AA$ / in top, and the change of pure [u:] to [ju:] in suit in Norwich (Trudgill (1986), 35; Leitner (1983), 111). With increasing education and higher social standing there is a more general and regular use of prestigious speech forms everywhere in England, including /U/ for Northern [ن̈] in cup, [a:] for Northern [æ] in dance, [RP /A:/], or the shortening of Southern regional long [i] in ready (Trudgill (1979), 10; (1983), 48). A rising awareness of the advantages of standard speech together with the possibility for nearly everyone to pick up standard forms on radio and TV have steadily increased the range of lasting modifications towards the prestige accent. Consequently, there has been a widening range of modified speech (cf. A. C. Gimson: "modified regional", (1980), 91) down the social scale and a tendency towards closer approximations to $\boldsymbol{R} \boldsymbol{P}$ on its upper levels, towards the apex of the "cone".

Striving for social recognition and success, many of lower middleclass background are displaying a snobbishly affected quasi-RP in their more or less successful attempts at “Oxford English". It was frequently argued that the prestige accent cannot be learnt without an appropriate social background and public school. Indeed, many of lower middleclass origin later remain speech-conscious, lacking control of the more subtle characteristics of connected speech such as assiminations, 
elisions and intrusive $\mathrm{r}$ in their Adoptive RP (cf. J. C. Wells (1982), 283). In their desire to avoid stigmatized speech and to use highprestige forms they carry linguistic adaptation to extremes ${ }^{5}$, and hypercorrections like $[\cdot t . S \hat{i} k \hat{e}=]$ or $[\cdot g a: d \hat{\imath}=](i b .27,262)$ in the "refined" speech of the socially ambitious lower middle-class prove linguistic insecurity as well as lack of social confidence. In educated speech, however, adaptations in the direction of the prestige accent have gone so far that there are now many with only mild regional affiliations in an otherwise $\boldsymbol{R P}$-like speech (cf. J. C. Wells "Near-RP", see below) and a realistic appreciation of the percentage of $\boldsymbol{R P}$-speakers in England (about $3 \%$ in 1979; cf. Hughes, Trudgill (1979), 3) has become increasingly difficult and largely questionable altogether, depending on how tolerant the judgement has been. For in the same way as the prestige accent is socially no longer the "exclusive property of a particular social stratum”, (Gimson (1980), 89), it is slowly but gradually losing its linguistic exclusiveness, becoming assimilated by those who are socially "arriving" and in their speech advancing the tip of the "cone". This is the range where upward convergence ends up in the mixing of accents near the upper end of the scale, thus providing the basis for further linguistic development on grounds of new social relations (cf. Trudgill (1983), 56).

\section{Post-War educated English English}

\subsection{The newly educated}

Language contacts were affecting the traditional speech hierarchy most visibly and intensively in the fields of secondary and higher education, traditionally the domain of the upper and upper middle classes. After the War the new economic situation with its increasing demands for highly qualified staff brought unprecedented educational opportunities and easier access to universities and colleges for members of the lower social strata. In the mid-forties, professional or academic careers had become open to great numbers of people from diverse social backgrounds with the expansion of the existing educational institutions, the

5 For American English, the phenomenon is reported as the "crossover of the secondhighest class", whose speakers are even exceeding those of the highest class in their extensive use of prestigious speech forms (cf. Bailey (1973), $176 \mathrm{ff}$.). 
foundation of the New Universities in the 1960's, the flood of technical colleges, universities, polytechnics and colleges of education as well as a host of new degree courses and the Open University since 1971. Between the Education Act of 1944 and the year 1966, the number of universities almost doubled, with four times as many students as before the War (cf. Mountford (1966), $18 \mathrm{ff}$.). In all those years considerable numbers of young people of lower middle- or working-class background - 28 per cent each in 1968 (cf. Cook 4) - took up their studies particularly at the newly founded polytechnics, newer universities and special colleges and, more recently, also at London University or even at the traditional upper-(middle)-class universities of Oxford and Cambridge taking 55 per cent of their students from state schools in the late 1970's. As regards secondary education, there were already 25 per cent of pupils taken over from primary schools by state-financed direct grant schools with public school status by the same time (cf. Bourke (1979), 110, 119). Those post-War measures in education brought quick and decisive changes in the social structure of schools and colleges and also of professional circles so that by 1951 about 50 per cent of those in professional and executive occupations were sons from the lower strata (cf. Trim (1958), 31; Wright (1974), 235), and ten years later most professional people were not original $R P$-speakers.

Of course, most of the newcomers to the social scene exhibited in their speech more or less easily noticeable regional features, which for the first time massively invaded the realms of the social élite. But as the "shape of linguistic behaviour changes rapidly as the speaker's social position changes" (Labov (1968), 240), many were ready and able in their future careers to modify their local speech forms after the model of the traditionally educated, and their mildly accented speech became acceptable in the same way as its carriers were tolerated in the world of the well-born and successful. So at least in the 1970's, the possible climax of regional impact on educated English, even Northern forms as [kÜp] or [giæs] had in the minds of many a "perfectly acceptable image" (Bourke (1979), 51). Whereas nowadays dialectal [ن̈] is usually changed to /U/ in the speech of Northerners coming to stay in the South and Cockney [f] becomes $/ Q /$ in thing in the speech of the socially ambitious, regional remains as short Northern [a] in bad or the high frequency of glottal stops as typical of popular London and several other traits of regional speech may still betray the local affiliation of 
educated speakers (Leitner (1981), 248; Trudgill (1983), 45). Their Near-RP (cf. P. Trudgill (1979), 10; J. C. Wells (1982), 297 ff. 301) may also contain a Southern vocalized $/ \mathbb{I}$ as in hill [hêÜ] beside a closer final [ذ̇] for /ê/ in many and a more fronted [Á:] for /u:/ in cool (Trudgill, Hannah (1985), 12), a final or medial /g/ as in tongue and singer of a North West Midland origin (Ellis (1972), 878) and the widespread use of / '/ for /ê/ in weakly accented syllables, including the inflections -ed and -es e.g. in wanted, horses, coming from many English dialect areas except the South East (Gimson (1979), 155 f.; Lewis (1985), 250; Trudgill, Hannah 12). The fact that in the last few decades traditional $\boldsymbol{R} \boldsymbol{P}$-speakers had to share their social world and language with a growing number of speakers who, to varying degrees, preserved regional affiliations in their speech could not remain without consequences for the prestige accent.

\subsection{Change in RP "from below"}

Sociolinguistic change proved a potential base for language change (cf. Bailey (1989), 12; Blount, Sanches (1977), 5; Milroy (1980), 19) insofar as the pentration of the traditionally educated social spheres by locally accented speakers was responsible for a growing number of regional features in otherwise prestigious speech. What was most striking about the post-War development of $\boldsymbol{R P}$ was that for the first time local speech forms other than those of the South East could decisively influence its traditional pattern. So extra open /æ/ as found in the North, the Midlands and Wales (Leith (1983), 133; Wells (1970), 246), the schwavowel / ' / in a growing number of endings like those on -ity, -ate, -less and -ness and even perhaps in the inflections -ed and -es (Gimson (1979), 155 f.) have meanwhile become generally received, and intrusive $r$ as a feature of Warwickshire and the South East Midlands in Chinaã[r]ãand or ideaã[r]ãof has become so usual that speech without it seems artificial, stilted or even foreign (cf. Trudgill, Hannah (1985), 15). Besides, originally South East English monophthongizations of diphthongs and triphthongs in day [dE:] or shower [S A:] (Gimson (1980), $129 \mathrm{ff}$.$) , the [?] - allophone of /t/ in positions like football, not$ yet, etc. (ib. 170; Leith (1983), 132, 138) and final [i] for /11 in city [·sêti] or coffee [·k̊̊fi] (Wells (1982), 299) are now widely accepted trends. Quite recently it seems as if there was an increasing number of 
London and South East English popular tendencies such as the fronting of / $\ddot{\mathrm{U}} /$ to [-1] in cook (inf. J.-C. N. Bailey) and a most recent closing of $/ \pi$ / to $[\mathrm{E}]$ among the very young (native speaker informant) in opposition to the general post-War fashion towards [ä] or even [A< ] (s.a.; cf. Gimson (1980), 109). Strengthened by a great vernacular loyalty and furthered by the general attraction of the Capital for the young generation, lowerclass London speech may even be considered "the most influential source of phonological innovation" (Wells (1982), 301) in the English of today.

In connection with the post-War development of the accent $A$. $C$. Gimson, in the late seventies, applied his new term revised $\boldsymbol{R P}$ to a "more relaxed but acceptable type of pronunciation" (cf. (1979), 154, $155 \mathrm{f}$.) including the elimination of / $\ddot{\mathrm{U}}$ '/ in favour of $/ O: /$ in sure, tour, etc. ${ }^{6}$ beside certain traits of regional influence. In consequence of the new and more permissive attitudes he also included in his $1977 \boldsymbol{E P D}$ the widespread replacement of unstressed / 11 in endings on -less and ness by the central vowel /'/. Linguistic borders were open to what he called wider-based $\boldsymbol{R P}$ "with the ... admission into the permitted speech forms of certain variants until recently regarded as regional" in his 1980 IPE ((1980), 102). What was "revised" or "wider-based" in A. C. Gimson's terms, has meanwhile become the usual way. J. C. Wells' Mainstream $\boldsymbol{R P}$ - in his words now "the central tendency" ((1982), 279) - includes most of the former regionalisms mentioned above, among them intrusive r (cf. ib. 286), a strongly lowered /æ/ (i.e. [ä] similar to fronted /U /, ib. 291 f.), backer starting points of /âa / and /ä̈/ as well as various monophthongizations of diphthongs and triphthongs (cf. ib. 292 ff.). So many of the regionally-based post-War trends have settled down with the middle and younger generations, leaving the accent more variable than ever before. Though, it is now hard to say which of these fashions will survive their carriers, and whether or not regional speech will continue its influence on $\boldsymbol{R P}$ in a different social climate with possibly less social innovation and a resulting consolidation of speech habits (s.b. BBC English).

According to the general rule, change in the prestige accent was predominantly caused by "those centrally in the hierarchy" (Labov $(1980), 254)$, i.e the upwardly mobile lower middle class, and it goes 6 Now, again, [O:] is considered old-fashioned against $\left[{ }^{\prime}:\right]$ is sure by the young generation (personal information by J. C. N. Bailey). 
without saying that the kind and degree of acceptability of those regional characteristics in upper (-middle)-class speech varies considerably with social status and generation. While members of the older and middle generations will base their judgements largely on post-War criteria and be more reticent in the acceptance of former localisms, there will be much more tolerance among younger people with their relatively unconventional speech habits. These recent developments have made it increasingly difficult to define $\boldsymbol{R P}$ linguistically and socially as well, so that by 1979 A. C. Gimson considered it "no longer possible to make a precise correlation of a 'received' standard of pronunciation with any section of society" ((1979), 154; cf. (1984), 46, 48). Although the prestige accent has remained the characteristic speech form of the upper social strata as regards status and occupation of its speakers, their social origin may now range from the traditionally $\boldsymbol{R} \boldsymbol{P}$-speaking upper and upper middle classes well down to a middle- or even lower middle-class background. This as well as serious doubts about the "received" character of the accent (cf. Bailey (1987), 403; Macaulay (1988), 115 ff.) have led to alternative definitions and terms dismissing "RP" from the inventory, e.g. J. W. Lewis' “Conspicuous GB" and "(ordinary) General British (GB)" (255) or C.-J. N. Bailey's "fashionable English” in contrast to a standard notion (cf. (1987), $400 \mathrm{ff}$.). However, in R. Macauley's view, "... the sooner the term is dropped the better chance there is that the serious study of English speech will advance" for "there is no such entity as $\boldsymbol{R P}$ except as a prescriptive model for the upwardly mobile” ((1988), $121 \mathrm{f}$.).

\subsection{Growing regional prestige}

Besides those who were modifying their regional accents in the direction of prestige forms, there were growing numbers of educated speakers deliberately keeping to local speech in order to demonstrate their affiliation to the land and the ordinary people. Post-War changes towards a more fluid society had made the barrier between regional speech and "Oxford English" more obviously felt than before, and the traditional upper(-middle)-class accent was considered a form of discrimination no longer reflecting social reality by the young from lower middle- and working-class homes, particularly those studying at universities and colleges. It was the time of great activities in the 
Campaign for Nuclear Disarmament, of campaigns against the Vietnam War, and of close contacts and solidarity with the Trade Unions in the students' unrest of the sixties (cf. Cook (1976), 6, 13 ff.). Student teachers, engineering, natural science and medical students were most open-minded to liberal ideas, many of them deriving from lower social strata themselves and preparing for jobs closer to the working class - as salary earners - than those in the traditional professions of the Law, the Church, and the Arts. What was an absolute novelty in academic life, the vast majority of students followed in their language attitudes those of working-class background - about one third in 1964 (cf. Atkinson (1975), 69) - in deeply despising "posh" together with the Establishment and the social system as a whole. With the values and traditions of their fathers, the post-War young were also questioning the so far generally accepted habits of educated speech and social conduct of previous generations while showing a rising pride in local language and culture and exhibiting their local speech consciously and deliberately. Not only at the newer universities, colleges and polytechnics but even at Oxbridge students began to display regional affiliations in their speech, and those who were $\boldsymbol{R P}$-speakers from home, fearing sneers at careful pronunciation, were deliberately adopting regional features (cf. Quirk (1980), 7, 12 f.). Anything would do that was not socially conspicuous, be it Liverpool, Cockney or pseudo-American, with the local and the popular becoming "an 'in' thing along with other forms of revolt against a traditional Establishment attitude” (Ellis (1972), 878). The sociolinguistic effects of the post-War general climate were showing in the speech of the middle generation in the 1960's and 70's when increasing numbers of the professional classes, among them even public school teachers, were quite openly rejecting $\boldsymbol{R P}$. Regional affiliation often stepped back behind a strong feeling of identity with the purely social background in lower middle- or working-class speakers, who were deliberately refusing to give up their local accents in favour of a career in order to separate "the newcomer-to-status from the aristocrat” (Robinson (1973), 439; cf. Trudgill (1974), $80 \mathrm{ff}$.). For them the speech of their native environment had become an anchor to hold onto and to find their own identity in the "vulagar language of home” (Boomer (1976), 148). In those times $\boldsymbol{R P}$-speakers became more and more rare among the staffs of universities like Leeds and Newcastle - also among those who had been educated at public schools - and there 
were (and probably still are) lecturers even at Oxford displaying regionalisms in their speech and proud of it (cf. Atkinson (1975), $69 \mathrm{f}$.; Barnickel (1982), $220 \mathrm{f}$.). In the 1970's the articulation of educated Londoners was no longer identical with $\boldsymbol{R P}$ (cf. Abercrombie (1957), 50; Barber (1964), 25 f.,; Germer (1967), 11; Quirk (1972), 73), and by 1985 between 80 and 90 per cent, among them the most highly educated and those in highest positions in government and industry, were more or less consciously displaying mildly regional speech (cf. Lewis (1985), 247; Hansen (1992), 19).

Along with considerable social relaxation in occupational and public life, recent language developments have made the old contrast between the prestige accent and regional speech less severely felt and mild localisms increasingly accepted. There is no longer any need either to disguise one's accent or to promote its acceptability in educated speech, for the "living spoken English of educated people" (Quirk (1972), 98) has proved a successful challenge to "Oxford English". Now that the traditional speech hierarchy is broken and a wide social acceptance of regionally coloured speech is secured, the waves of linguistic rebellion are obviously dying down among the young. There even seems to be a recent "gap in accent evaluation", characterized by a "reduced sensitivity to accent values" (Lewis (1985), 253, cf. 249), which characteristically applies to mild regionalisms but not to obtrusively upperclass mannerisms and insofar continues the socio-cultural trends of post-War decades. The results of the struggle are simply taken for granted, at least so in the academic scene, and this with full justice: The attraction of regionalisms has become fairly general among the young, who now choose their speech quite often without noticing or worrying over language standards. Insofar as an increasing majority of students at universities and colleges are now regionally accented speakers from home, the trend towards the more democratic and generally acceptable will be likely to continue in the foreseeable future and may even further diminish linguistic contrasts.

\subsection{Upper Crust and Cockney}

In a time of various modifications of regional pronunciations towards "received" forms and, on the other hand, a rising prestige of mildly regional speech in educated English, the young social élite had its own 
ways of preserving the exclusiveness of Upper-crust (U) RP (cf. J. C. Wells (1982), $280 \mathrm{ff}$.), and their contribution to the development of the prestige accent was traditional as well as fashionable. With its social and linguistic basis in and around the Capital, the prestige accent had always shown strong resemblences to popular London speech, e.g. the conservative $\left[\AA^{\prime} *\right.$ * $]$ in before and [O:] in off (Gimson (1980), 115; Wells (1970), 239), and the new post-War trends were based on the same ground. At the public schools a considerable number of alumni have for decades been displaying South East English regionalisms beside various trendy fashions like wilful accelerations, refinements and spelling pronunciations to escape uniformity and routine. Markedly South East English regional features like strongly monophthongized forms of diphthongs and triphthongs, the glottalization of consonants, a considerable closing of /O:/ to [Q:] in saw, and a fronting of /U/ to [ä] or ['] in luck (Barnickel (1982), 41 ff.; Eustace (1967), 305; Gimson (1964), 135) are all very near to London Cockney or South East English country dialects. There are now even Southern dialectal pronunciations in upper-class speech which are not by all regarded as standard, e.g. the extra strong monophthongization of /ẫ'/ to [a:] as in fire or the diphthong / ' Ü/ instead of the monophthong / $\AA$ / in solve (Brook (1979), 32). Beyond that the variant also contains diphthongizations as in $\operatorname{did}$ [1 1 ], head [e'] and bad [æ'] (Gimson (1964), 133), which are without equivalents in popular London, and the originally Northern and South Western trend to [ä] instead of /æ/ as a general feature of post-War educated English (s.a). Nevertheless, the variant fully deserves the label of "Metropolitan sub-variety" (Lewis (1985), 250), socially as well as linguistically.

Just in the tradition of prestigious speech, the London and South East English localisms set their speakers off from other regional affiliations and social backgrounds as well as from the older generations with their more moderate speech habits. Beside the traditional attraction of the Capital, the new post-War language contacts in education and professions and the recent image of the hard-working and successful young Cockneys "gaining the prestige that often goes with wealth" (inf. Bailey) will have strengthened South Eastern regionalisms in $\boldsymbol{U}-\boldsymbol{R} \boldsymbol{P}$. Moreover, the extremely strong orientation of the young post-War élite, even that of the Royal family (cf. Gimson (1964), 132 f.), on London Cockney may be a contrastive upper-class reaction on the increasing 
appearance and acceptability of regional low-prestige characteristics other than South East in educated English. On the whole, the trendy Cockney fashion in $\boldsymbol{R P}$ seems to be based on a complex of more or less conscious psycho-social motivations, including traditional language attitudes and recent changes in the relations between social groups and classes as well. For decades the influence of this London-based $\boldsymbol{a d}$ vanced variant on the development of the accent has been unquestioned (cf. ib. $132 \mathrm{ff}$.), and the Metropolitan sub-variety of today will also leave its marks on prestigious speech. Only, under the present conditions this all-too obviously upper-class accent seems to become more of a socially insulated in-group variant with decreasing acceptability among the young outside the exclusive circles, and its social "conspicuousness" (Lewis (1985), 253) may diminish its influence which probably will not go so far down the social scale into middleclass speech as it did in the first decades after the War. There is now good reason to assume that the regionally influenced and more generally accepted wider-based branch of $\boldsymbol{R P}$ (s.a.) will leave more decisive traces on tomorrow's educated English than the conspicuous, though highly prestigious, upper-class variant can in the foreseeable future.

\section{The BBC's response to the new situation}

\subsection{Local stations and relaxed standards}

In the last few decades the British Broadcasting Corporation (BBC), which from its very beginnings played an active role in the strengthening of $\boldsymbol{R} \boldsymbol{P}$, has accommodated its style to the new situation. Along with the growing prestige of regionally accented speech and stimulated by the necessity to compete with the much less exclusive language usage on TV, local radio stations began to broadcast their own programmes in the speech of the respective regions in 19547. Particularly in North England and Wales those transmissions proved important stimuli in the further adherence to local speech as well as its acquisition in adult life. In Wales, claims to sustain the command of the Welsh

7 Educated national accents of Ireland, Scotland and Wales and also educated Northern English, in contrast to all other accents of England, had been acceptable in the early years of the $\boldsymbol{B B C}$, but with a clear bias (cf. Leitner (1982), 102, 106; (1989), 15, 22). 
language by radio and television transmissions came from all social classes, but predominantly from college students and other young people in connection with the world-wide anti-colonial atmosphere historically, Wales is a conquered country - and the new social situation. After the Welsh Education Act of 1967, local language programmes were transmitted seven hours per week each by BBC Wales and on television (cf. Khleif (1979), 63). About ten years later, in 1980, about half of the Welsh-speaking population (i.e. about twenty per cent of the total) voted for daily programmes in Welsh (cf. Bellin (1984), 470) to prevent a further decline of the language and of the traditional social ties and cultural values. Following the general trend, London, too, got its local station (Capital Radio London) for entertainment and news bulletins, with a board decidedly anti-RP ("None of us here are familiar with the term 'conservative RP' ..."; cf. Leitner (1979), 40, 92) but aiming at a clear articulation in the sense of educated London speech, which is no longer socially exclusive.

While local radio and television are outstanding reflections of new language attitudes, the less spectacular changes in the regular transmissions of the $\boldsymbol{B} \boldsymbol{B C}$ and other British stations ${ }^{8}$ also reveal important speech trends of the time. In general, the presentation has become much more relaxed and popular (cf. Leitner (1989), 13), depending on the topic and style of the issue, and there are a number of articulatory novelties, trendy fashions and mild regionalisms of all kinds in the speech of commentators, reporters and entertainers. In the range of $\boldsymbol{R P}$ vowels and diphthongs, the originally Northern and South Western extra open realization of /æ/ as in and [ä:nd], actual [(äktS ['] 7 ] or Buckingham palace [·pälis], the originally South Eastern open first element or its extensive lengthening towards monophthongization as in game [gaîm], players [p]E: ['Lłand bye-bye [ $\cdot \mathrm{ba}$ :, ba: $\mathrm{i}]$ are among the most obvious changes. In fifteen minutes commentaries by different speakers, the diphthong / $\hat{I}^{\prime} /$ in year was overwhelmingly realized as

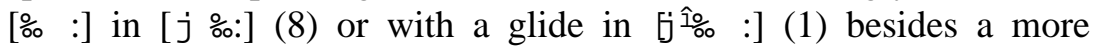
conservative [ $\left.\hat{\mathrm{I}}^{\prime}\right]$ in [ $\left.\hat{\mathrm{l}}^{\prime}\right](2)$, all this together with assimilations in

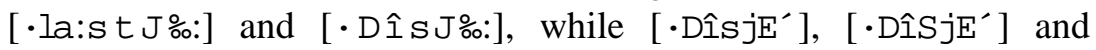
[b:sCE.] were also found on other occasions. Mild former regionalisms are colouring the picture, as an intrusive $\mathrm{r}$ in draw it

8 For the sociolinguistic pattern of post-War radio and television cf. G. Leitner (1983), 59; R.W Burchfield and T. Tim in: Burchfield et al. (1979), 13 ff. and $21 \mathrm{ff.}$ 
[-drO:绝] out, an occasional North West Midland medial /g/ in singer $\left[\cdot \mathrm{s} \hat{\mathrm{I}}=\mathrm{g}^{\prime}\right]$, a clear Northern [a] in passage [-pasîdJ] of a bill, a slightly raised Western [ä] in after all [ä̈ft' $\mathrm{rO} \cdot:\urcorner$ ], or both in connection with widely dialectal vocal $/ d$ in forecast $[\cdot f O \cdot r k a \cdot s t]$ and [·fO·rkäst], resp. Further, there are mannerisms and idiosyncracies like unusual stresses in 'controversial, the 'situation or the value 'of it, and assimilations and elisions like [ ${ }^{a}$ güb • bâ̂] ( good-bye), [· jesi dê̂] (yesterday) and [ $\left.\cdot \mathrm{s} \stackrel{\circ}{\circ}: n_{i j}\right]$ (certainly), also at word boundaries as in [· wÅt S'a neîm] (What's your name?) or [·æJju. asê̂] (As you say), particularly so in the speech of disc jockeys and sports commentators following the trends of their young audiences. Althogether, it is a relaxed, easy-going speech style, conforming with the speech habits of the younger generations and with their preference for the local and the popular 9 .

\subsection{Trends in newsreading}

With regard to the speech of $\boldsymbol{B} \boldsymbol{B C}$-newsreaders, opinions may widely differ as to the kind and degree of articulatory change ${ }^{10}$ over the last few decades. While English regional affiliations were noted besides Commonwealth articulations (cf. Gimson (1977), 56; Quirk (1972), 72; (1980), $8 \mathrm{f}$.), there was also the impression that in spite of a great deal of relaxation in pronunciation and style there were "no very markedly non-RP accents at least among the principal newsreaders" (Lewis (1985), $252 \mathrm{f}$.) and the articulatory novelties on the news were mainly the result of "the general process of language change" in the different generations of $\boldsymbol{R P}$ speakers (Gough (1982), 247 f.). Indeed, BBC newsreaders are reflecting in their speech the changes that educated English pronunciation in general and the $\boldsymbol{R} \boldsymbol{P}$-accent in particular have undergone in recent decades. The considerable relaxation of speech habits even on formal occasions becomes evident in a great number of assimilations and elisions as in suggestion $\left.\left[\mathrm{s}^{\prime} \cdot \mathrm{dJeS}_{\mathrm{i}} \mathrm{i}^{[}{ }^{\prime}\right] \mathrm{n}\right]$, accident $[\cdot æ k s d ' n t]$ and almost regularly in negotiations [ni g ' $\left.\mathrm{U} \cdot \mathrm{Sje} \hat{\mathrm{I}}\left[{ }^{\prime}\right] \mathrm{nz}\right]$, police [pi:s]and government [• gUvm ['] nt] in the news broadcasts. Beside that, former regionalisms such as the

9 The examples given here were taken from broadcasts of the $\boldsymbol{B} \boldsymbol{B} \boldsymbol{C}$ National Programme and the BFBS in Germany between 1977 and 1990.

10 Phonological analysis of BBC-English cf. G. Leitner (1979), $45 \mathrm{ff}$. 
widely used schwa-vowel /'/ even in world-final -ed and -es, the originally Northern extra open vowel in damage [ä] and its extremely lengthened variant in and [ä:], the characteristically South East English monophthongizations in year [F: ['] ] or [j o:], hours, [A [ha: $\left.{ }^{\left[{ }^{\prime}\right]}\right]$, lower $\left[1\right.$ ㅇ: $\left.:^{[\prime]}\right]$, Europe $\left[\cdot\right.$ j०: $\left.{ }^{\left[{ }^{\prime}\right]} r^{\prime} p\right]$ can frequently be heard on the news of the BBC National Programme. Even the BBC World Service with its traditional conservativism and its high linguistic standards is paying tribute to recent exclusive fashions, particularly with regard to an extremely open and centralized [ä] for /æ/ as in matter [ - mät'] or strategy [-strätîdjî] and to various strongly monophthongized forms as in fire [fA: $\left.{ }^{[\prime}\right]$, town [ta: $\left.{ }^{[\prime}\right]$, and sure [S O:] in the range of post-War advanced $\boldsymbol{R P}$. Usually the vowel in and is even longer and more open and diphtongs are still further reduced than in the domestic news where public criticism has kept exaggerations and mannerisms within comparatively narrow borders 11 .

\subsection{Public criticism and traditional policies}

In all these years speech on the $\boldsymbol{B} \boldsymbol{B C}$, in spite of its traditional prestige all over the country, has met with a considerable amount of criticism from different sides. In connection with the trend towards the regional and the popular among the young generation, there were demands for more regional accent, linked with the argument of "posh" being outdated and unnatural (cf. Leitner (1983), 68 ff.; Zimmermann 227 ff.). In the same way as those hopes were fulfilled, letters of complaint were pouring in from conservative circles of the older generation, calling for more standards, particularly in connection with politics ${ }^{12}$. Regionalisms of any kind, e.g. "sub-Northern" [U] for /æ/ in back, were rejected (including even protests from the respective region!) and anything that was not $\boldsymbol{R} \boldsymbol{P}$ or did not fully correspond to spelling, as [?] for /t / or intrusive r, was stamped "careless" or "slovenly" (Gimson (1980), 89; Leith (1983), 117). In the same way recent innovations and mannerisms of the show-business, like neutralizations and contractions

11 These and further examples were taken from the BBC National Programme and the BBC World Service between 1977 and 1991.

12 Similary, there had been ardent pyublic protests on the "Stilted Voice" on the $\boldsymbol{B} \boldsymbol{B C}$ in the 1920's already (cf. Leitner (1979), $1 \mathrm{ff}$.) and, on the other hand, complaints over trendy fashions in the articulation of ist newsreaders in the 1930's (cf. Brook (1979), $165)$. 
of sounds in businessm(e)n, af(ter)noon, etc., the lengthening of the

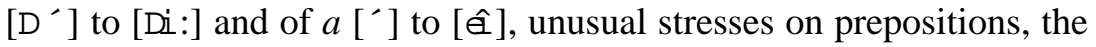
fronting of word accents (marked a "transatlantic offence") as well as unaccustomed word usage and syntax came under severe attack (Zimmermann $430 \mathrm{ff}$.). There was also quite a lot of argument over American English traits in the language of the $\boldsymbol{B} \boldsymbol{B C}$ in connection with the preference of the young for a pseudo-American accent in peergroup speech as well as entertainment (cf. Gimson (1979), 150; Gough (1982), 247; Trudgill (1983), 141). Altogether, the main trend of public criticism was against regionally accented speech as well as socially conspicuous innovations and mannerisms. In all that linguistic ramble the $\boldsymbol{B B C}$ World Service was able to keep its outstanding prestige, though by far not devoid of articulatory novelties in its own ranks (see above). It was as if South East English fashionable trends and mannerisms were going without serious criticism, more willingly granted by the public to a station aiming at oversees audiences than to domestic radio representing what is widely taken for a "neutral national standard” (Bellin (1984), 38; cf. Weiner (1986), 227).

Obviously, the loosening of standards on domestic radio - regardless how far it ever got in newsreading - seems to have lost speed and intensity in recent years. In the 1970's already, R. Quirk supposed that a reaction might set in, as people grew "anxious about unending permissiveness - or ... bored by it” (Quirk (1972), 72), and A. C. Gimson pointed to the "less permissive attitude of the BBC to its newsreaders" (Gimson (1979), 150; cf. (1984), 46). New language attitudes became evident in the 1980's or even earlier when the trend towards the colloquial and the popular seemed to have passed its zenith. Sometimes, even, almost "conservative" versions were to be heard, like [dê̂], [taîm], [snou], [ $\left.\hat{\jmath}^{\prime}\right]$ (but fashionable[fa:'] and [fa:] for fire from the same newsreader!), and occasionally assimilations were avoidded in words like association and negotiation. The $\boldsymbol{B B C}$ itself contributed to this development with a considerable number of discussions and investigations of the standard of the language for which the Board had always been feeling largely responsible since the early days of the Advisory Committee on Spoken English in the 1920's (cf. Leitner (1989), 9). A Report for the $\boldsymbol{B B C}$ of 1979 again showed much concern and the conviction that the $\boldsymbol{B B C}$ had "a clear duty to uphold the standards of spoken English, currently under criticism” (Timothy (1979), 
24). Beside an obvious readiness to accept changes firmly established in current usage, the general trend seemed to be the maintenance of a relatively conservative language tradition, with $\boldsymbol{R} \boldsymbol{P}$ as the de facto standard of pronunciation in the news and political commentaries. Today the speech of $\boldsymbol{B} \boldsymbol{B C}$-newsreaders on domestic radio contains no more than the usual set of meanwhile generally accepted post-War novelties beside a relatively small number of widely received former regional features. What has remained of the "linguistic revolt" of post-War time in the news on today's BBC National Programme, is a careful, unobstrusive and unconspicuous variant very near to what A. C. Gimson described as High Acceptability RP in the early 1980's ((1984), 51).

Considering the traditional language reputation of the $\boldsymbol{B B C}$ as a whole and its unquestioned role as a model of educated speech for large parts of the English population and also abroad, its effects on the language are unquestionable. With its news broadcasts and commentaries it has promoted prestigious trends and innovations and in doing so contributed to the stabilization of upper(-middle)-class fashionable English among the younger generations. Further, through its influence it has encouraged modifications of regionally accented speech towards the prestige model on various scales. But at the same time it has also been "promulgating regional accents throughout the nation" (Giles, Powesland (1975), 27), thus stimulating socio-regional or ethnic convictions. Together with British TV, which from the start had based on more popular grounds than the radio, the $\boldsymbol{B} \boldsymbol{B C}$ with its new informal speech style loosened social bonds, encouraged growing tolerance in accent evaluation and, beyond that, made the young different from their parents in many other respects than language (cf. Bolinger (1980), 50 ff.). This is not to overestimate the socio-linguistic influence of the media but to underline their role in the "give and take" of a largely mobile social world.

\section{Conclusion}

It was an extraordinarily dynamic time after the War, leaving its marks on the speech habits and evaluations of all social strata and bearing its consequences for the further development of the language. Upward mobility and the resulting language change from below widened the range of $\boldsymbol{R P}$ socially as well as linguistically, diluted its originally London-based pattern by various English regional features and left it 
more linguistically complex and socially acceptable for a wider scope of local loyalties, class affiliations and generations. Putting an end to the social exclusiveness of the prestige accent in education and the professions and at the same time inducing new and more democratic developments in its articulatory pattern, English socioregional accents have been a challenge and a stimulus as well. Never before, however, the justification of a standard language for the country and of binding articulatory norms for educated speech had been so seriously questioned, and at no time localisms had been so deliberately cultivated and proudly defended as in those post-War years. When many of the young educated of lower middle- or working-class background began to develop a strong sense of socio-regional identity through speech and were refusing to abandon their local accents in favour of upper(middle)-class prestige forms, they were setting an example for generations to follow. While the "Oxford accent" is still surviving as a status symbol of the social élite, various regional affiliations will continue to be involved in the shaping of a generally acceptable educated English English.

\section{References}

Abercrombie, David (1957): Problems and Principles. London. New York. Toronto.

Abercrombie, David (1965): Studies on Phonetics and Linguistics. London

Atkinson, R. E. B. (1975): RP and English as a World Language. In: International Review of Applied Linguistics Vol. XIII/ 1.

Bailey, Ch.-J. N. (1973): The patterning of language variation. In: R. W. Bailey, J. L. Robinson (eds.), Varieties of present-day English. New York.

Bailey, Ch.-J. N. (1987): Fashions in English or standard? In: Multilingua 6 - 4.

Bailey, Ch.-J. N. (1989): The True/ False Principles of Language Change. In: Indogermanische Forschungen 94.

Barber, Charles (1964): Linguistic Change in Present-Day English. London.

Barnickel, K. D. (1982): Sprachliche Variationen des Englischen - nationale, regionale und soziale Varianten. München

Bellin, Wynford (1984): Welsh and Language in Wales. In: J. C. Wells (ed.), Language in the British Isles. Cambridge.

Blount, G. B.; Sanches, Mary (eds.) (1977): Sociocultural Dimensions of Language Change; Introduction. New York.

Bolinger, Dwight (1980): Language - the Loaded Weapon. London. New York. 
Boomer, Gerth; Spender, Dale (1976): The Spitting Image. Reflections on Language, Education and Social Class. Adelaide, Sidney, et al.

Bourke, John (1979): Britain. A Short History for Students of English. München.

Brook, J. L. (1979) Varieties of English. London.

Burchfield, R. W.; Donoghue, D.; Timothy, A. (1979): The Quality of Spoken English on BBC Radio. A Report for the BBC. London.

Cook, Dave (1976): Students. London.

Ellis, Stanley (1972): BBC and other English. In: Times Literary Supplement.

Eustace, S. S. (1967): Present Change in English Pronunciation. In: Proceedings $6^{\text {th }}$ International Congress of Phonetic Sciences. Prague.

Germer, Rudolf (1967): Wesen und Wandlung der (Received Pronunciation( seit Jones. In: Neusprachliche Mitteilungen 1.

Giles, Howard (1971): Patterns of Evaluation in Reaction to R. P., South Welsh and Somerset Accented Speech. In: British Journal of Social and Clinical Psychology 10.

Giles, Howard (1972): Evaluation of Personality Content from Accented Speech as a Function of Listener(s Social Attitudes. In: Perceptual and Motor Skills 34.

Giles, Howard (1975): Speech Style and Social Evaluation. London, New York, San Francisco.

Giles, Howard; Powesland, P. F. (1975): Speech Style and Social Evaluation. London, New York, San Francisco.

Gimson, A. C. (1964): Phonetic Change and the RP Vowel System. In: D. Abercrombie (ed.), In Honour of Daniel Jones. London.

Gimson, A. C. (1977): Daniel Jones and Standards of English Pronunciation. In: English Studies 2.

Gimson, A. C. (1979): English RP: Ancient or modern. In: Praxis des Neusprachlichen Unterrichts 2.

Gimson, A. C. (1980): An Introduction to the Pronunciation of English. London.

Gimson, A. C. (1981): The Twentyman Lecture, 1981: The Pronunciation of English: Its Intelligibility and Acceptability in the World. In: Modern Languages LXII, 2.

Gimson, A. C. (1984): The RP accent. In: J. C. Wells, Language in the British Isles. Cambridge.

Gough, John (1982): Broadcast English. In: Zeitschrift für Anglistik und Amerikanistik 3.

Halliday, M. A. K. (1968): The Users and Uses of Language. In: Fishman, J. A. (ed.), Readings in the Sociology of Language. The Hague, Paris.

Hansen, Klaus (1986): Arten und Ursachen der Sprachvariation. In: Zeitschrift für Anglistik und Amerikanistik 3.

Hansen, Klaus (1992): Das Englische in England als nationale Variante des Englischen. In: Zeitschrift für Anglistik und Amerikanistik 1. 
Hughes, Arthur; Trudgill, Peter (1979): English Accents and Dialects. London.

Kelman, H. C. (1972):Language as Aid and Barrier to Involvement in the National System. In: J. Fishman, Contributions to the Sociology of Language. The Hague, Paris.

Khleif, B. B. (1979): Language as an Ethnic Boundary in Welsh-English Relations. In: International Journal of the Sociology of Language 20.

Köppl, S.: Schmied, J.; Schneider, E.; Viereck, W. (1983): English. Formen und Funktionen einer Weltsprache. Ausstellung des Lehrstuhls für Englische Sprachwissenschaft und Mediävistik und der Universitätsbibliothek. Universität Bamberg.

Labov, William (1968): The Reflection of Social Progress in Linguistic Studies. In: J. Fishman (ed.), Readings in the Sociology of Language. The Hague, Paris.

Labov, William (1972): The Study of Language in ist Social Context. In: Pride, Holmes, Sociolinguistics. Harmonsworth.

Labov, William (1980): The Social Origins of Sound Change. In: W. Labov (ed.), Locating Language in Time and Space. New York, Toronto et al.

Laver, John; Trudgill, Peter ( 1979): Phonetic and Linguistic Markers in Speech. In: K. R. Scherer, H. Giles (eds.), Social Markers in Speech. Cambridge, London et al.

Leith, Dick (1983): A Social History of English. London.

Leitner, Gerhard (1979): BBC English and the BBC. Geschichte und soziologische Interpretation des Sprachgebrauchs in einem Massenmedium. In: Linguistische Berichte, LB-Papier Nr. 60, Braunschweig.

Leitner, Gerhard (1981): Soziolinguistische Aspekte der Aussprachenorm im Englischunterricht. In: P. Kunsman; O. Kuhn, Weltsprache Englisch in Lehre und Forschung. Festschrift für K. Wächtler. Berlin.

Leitner, Gerhard (1982): The consolidation of educated Southern English as a model in the early $20^{\text {th }}$ century. In: International Review of Applied Linguistics Vol. XX/ 2.

Leitner, Gerhard (1983): The social background of the language of radio. In: D. Howard; P. Walton (eds.), Language, Image, Media. New York.

Leitner, Gerhard (1989): BBC English und Englisch lernen mit der BBC, Berlin, München, Wien.

Lewis, J. W. (1985): British non-dialect accents. In: Zeitschrift für Anglistik und Amerikanistik 3.

Macaulay, Ronald (1988): RP R. I. P. In: Applied Linguistics Vol. 9, 2.

Milroy, Lesley (1980): Language and Social Networks. Oxford.

Mountford, Sir James (1966): British Universities. London

O'Donnell, W. R.: Todd, Loreto (1980): Variety in Contemporary English. London.

Orton, Harold; Sanderson, Stewart; Widdowson, John (1978): The Linguistic Atlas of England. University of Leeds, London. 
Robinson, J. L. (1973): The Wall of Babel; Or, Up against the Language Barrier. In: Ch.-J. N. Bailey, J. L. Robinson (eds.), Varieties of Present-Day English. New York, London.

Quirk, Randolph (1968): The Use of English. London.

Quirk, Randolph (1972): The English Language and Images of Matter. London.

Quirk, Randolph (1980): Sound Barriers and Gangbangsprache. In: L. Michaels, C. Ricks, The State of Language. Berkeley, Los Angeles.

Smith, J. B. (1969): Tradition and Language in an Urban Community. In: Lore and Language (2:2) 1 .

Spencer, John (1958): Received Pronunciation: Some Problems of Interpretation. In: Lingua 7.

Timothy, Andrew (1979): The Quality of Spoken English on BBC Radio. In: R. W. Burchfield et al, s. a.

Trim, J. L. M. (1958): English Standard Pronunciation. In: Lingua 7.

Trudgill, Peter (1974): Sociolingusitics. An Introduction. Harmondsworth.

Trudgill, Peter (1975): Accent, Dialect and the School. London.

Trudgill, Peter (1979): Standard and Non-Standard Dialects of English in the United Kingdom: Problems and Policies. In: International Journal of the Sociology of Language 21.

Trudgill, Peter (1983): On Dialect. Social and Geographical Perspectives. Oxford.

Trudgill, Peter (1986): Dialects in Contact. Oxford, New York.

Trudgill, Peter (1990): The Dialects in England. Cambridge/ Mass.

Trudgill, P.; Hannah, J. (1985): International English. A Guide to Varieties of Standard English. London.

Viereck, Wolfgang (1975): Regionale und soziale Erscheinungsformen des britischen und amerikanischen Englisch. Tübingen.

Wächtler, Kurt (1978): Sociolinguistics Aspects of a Phonetic Change in the RP-Model of British English. In: Linguistische Berichte 53.

Wakelin, Martin (1984): Rural dialects in English. In: J. C. Wells (ed.), Language in the British Isles. Cambridge.

Weiner, E. S. C. (1986): Pronunciation. In: I. C. B. Dear (ed.), Oxford English. A Guide to the Language. Oxford, New York.

Wells, J. C. (1970): Local Accents in England and Wales. In: Journal of Linguistics 2.

Wells, J. C. (1982): Accents of English I, II. Cambridge, London, New York.

Wright, Peter (1974): The Language of British Industry. London, Basingstoke.

Zimmermann, Gerhard (1982): Sprachkritik des Englischen am Beispiel der BBC. In: Die Neueren Sprachen 4. 